\title{
5
}

\section{Foreign policy making in the Middle East}

It is frequently claimed that foreign policy making in Middle East states is either the idiosyncratic product of personalistic dictators or the irrational outcome of domestic instability. In fact, it can only be adequately understood by analysis of the multiple factors common to all states, namely: (1) foreign policy determinants (interests, challenges) to which decision-makers respond when they shape policies; and (2) foreign policy structures and processes which factor the 'inputs' made by various actors into a policy addressing these determinants.

\section{Foreign policy determinants}

In any states system state elites seek to defend the autonomy and security of the regime and state in the three separate arenas or levels in which they must operate, although which level dominates attention in a given time and country may vary considerably.

The regional level: geopolitics In a states system like the Middle East, where regional militarisation has greatly increased external threats, these often take first place on states' foreign policy agendas. While, generally speaking, external threat tends to precipitate a search for countervailing power or protective alliances (or, these lacking, attempts to appease the threatening state), it is a state's geopolitical position that specifically defines the threats and opportunities it faces. It constitutes a state's neighbourhood where border conflicts and irredentism are concentrated and buffer zones or spheres of influence sought. Position determines natural rivals: thus, Egypt and Iraq, stronger river valley civilisations, are historical 
competitors for influence in the weaker, fragmented Mashreq; Iran and Iraq are natural rivals for influence in the Gulf. A state's power position in the regional system, shaped by its resources, size of territory and population and the strategic importance or vulnerability of its location, shapes its ambitions: hence small states (Jordan, Gulf States) are more likely to seek the protection of greater powers and larger ones to establish spheres of regional influence (e.g. Syria in the Levant, Saudi Arabia in the GCC).

The international level: dependency The impact of the core great powers and the international political economy constitutes a dilemma for regional states. The core is both the indispensable source of many crucial resources and of constraints on the autonomy of regional states. The constraining impact of the core ranges from the threat of active military intervention or economic sanctions to the leverage derived from the dependency of regional states, maximised where there is high need and a lack of alternatives for the client state. In extreme cases, foreign policy may be chiefly designed to access economic resources by appeasing donors and investors. Vulnerability to core demands, such as structural adjustment, can inflame domestic opposition. However, shared security and economic interests between the core powers and status quo elites may make such costs seem worth incurring.

The domestic level: identity In most Middle Eastern states identity is complex, with sub- and supra-state identities contesting exclusive loyalty to the state. Where sub-state identities are strong, they may produce irredentist pressures on decision-makers. Where suprastate Arab and/or Islamic identities are strong, regime legitimacy may be contingent on adherence to Arab-Islamic norms in foreign policy. This may mean contesting the penetration of the region by the core powers and it may de-legitimise relations with certain states: thus, while some Arab states have been pushed by economic dependency or security considerations to establish relations with Israel, these remain largely illegitimate at the societal level.

The impact of identity is not, of course, uniform. Where there are high levels of public mobilisation and low levels of state consolidation, elites are more vulnerable to Pan-Arab or Pan-Islamic opinion in foreign policy making. Because supra-state identity is often an instrument of opposition forces or of subversion by rival states, 
status quo elites have an incentive to create state-centric identities compatible with sovereignty and to pursue the higher levels of state formation that enhance their autonomy from such pressures. However, where revisionist social forces dominate states, they may foster and use supra-state identities in the service of their foreign policy.

\section{Decision-making}

Foreign policy making elites are 'Janus-faced', looking both inward and outward, attempting to reconcile demands from domestic actors with threats or constraints from external powers. Coping with a threat at one level normally requires accessing resources at another and maximising one value (autonomy, security, wealth, identity) may require sacrificing some of another. Thus, for example, to counter a regional threat may require protection by a core state, increasing dependency at the international level at a possible cost in domestic legitimacy. Conversely, mobilising the support of revisionist domestic forces in order to increase autonomy of core pressures may increase the risk of regional war or of economic sanctions from core states. The trade-off is well illustrated by the way the Rushdi affair caught Iranian elites between the need to preserve the domestic legitimacy derived from the Khomeini heritage, and the need, for economic reasons, to repair relations with Western Europe which this affair strained. According to David (1991), elites' rational choices determine policies, that is, their assessment of where the threat is greatest at a particular time. The highest rationality may be the ability to 'omni-balance' between threats at various levels.

However, because policy making is seldom simply a matter of a rational actor weighing costs and benefits to identify the one obviously best course of action and because, as constructivists insist, interests and threats, far from being self-evident, are a 'constructed', function of identity, a state's choices are 'filtered' by its historic foreign policy role (Holsti 1970). A role is a durable tradition rooted in identity that defines orientations toward neighbours (friend or enemy), great powers (threat or patron) and the state system (revisionist or status quo), and which incorporates a country's experience in balancing and reconciling conflicting imperatives. State/ regime formation is one decisive factor in shaping role; thus, Israel's conception of itself as a besieged refuge for world Jewry is rooted in its formation as a product of the Zionist movement. Geopolitical 
position is another: thus, Egypt's regional centrality led its decisionmakers to seek influence in the Arab East, North Africa and the Nile Valley. Although manipulated by elites, once a role is established and shapes the socialisation of the next generation of policy makers, it sets standards of legitimacy and performance, which, to a degree, constrain elites, imparting a certain consistency to foreign policy despite changes in leadership and environment.

Since roles seldom provide ready-made answers to particular policy dilemmas, the personalities, perceptions and misperceptions of leaders are inevitably pivotal in determining choices. Where elites are themselves competing in a process of 'bureaucratic politics' to promote rival policies, outcomes will be determined by the power distribution among them as shaped by the state's governing institutions. The interests and differential weight carried by different actors seeking to influence the ultimate decision-maker - public opinion, business, the military, diplomats - will bias the direction of choices; whether the internal power advantage is held by a nationalist/populist coalition or an infitah (internationalist) coalition may be decisive. Even if elites are united, they must constantly build or service the domestic coalitions that allow them the autonomy to make their choices and provide the power to sustain them.

Finally, outcomes depend on policy implementation, in part a function of the instruments of influence available to state elites such as economic rewards and punishments, propaganda machinery and military capabilities. But outcomes cannot be adequately explained merely by the balance of such tangible resources among states: the diplomatic skills and bargaining strategies of leaders, including intangibles, such as credibility and 'will', also count.

\section{The foreign policy process}

The following survey of the policy process examines the typical actors, with the least influential treated first and the most decisive last, while paying special attention to the consequence of the distribution of power among the latter.

'Outside' actors: inputs into the foreign policy process

Public opinion In the Middle East, public opinion normally plays little direct role in foreign policy formulation, which is everywhere, the special business of top elites. The majority of the population is 
often inattentive, uninformed, and divided by class or ethnicity, hence easily manipulated by elites on foreign policy issues. This is, in good part, because political opposition is typically repressed or co-opted and the press controlled. The public itself may be dependent on the patronage of a distributory state (especially in lowpopulation oil-rich states like Saudi Arabia or Kuwait) which trades economic benefits for political acquiescence. Accountability mechanisms are largely lacking in the Middle East and in most states elections do not allow the public to choose between different foreign policies or to hold leaders accountable for them.

When leaders have enjoyed external support or a consolidated base, they have routinely ignored public opinion and although they have paid a price, it has seldom been unacceptable. Thus, external support allowed King Hussein of Jordan to escape unscathed from his repeated defiance of public opinion, including his dismissal of an elected pro-Nasser government in 1957, his repression of the Palestinians in Black September 1970, and most recently his peace treaty and normalisation of relations with Israel. Asad of Syria, atop a consolidated regime at home, also defied public opposition to his 1976 intervention in Lebanon against the PLO, his alignment with Iraq in the Iran-Iraq war and his joining of the Western coalition against Iraq in the Kuwait crisis. Sadat defied the public and part of elite opinion in pursuing a separate peace with Israel; while this inflamed Islamic opinion, weakened the regime's legitimacy and played a part in his assassination and the subsequent Islamic insurgency Egypt faced, public opposition did not force a change in Egyptian foreign policy.

Leaders can also reshape public opinion. Nasser was the prime example of a charismatic leader who altered public opinion, bringing Egyptians to see themselves as Arabs and raising Arab nationalist consciousness across the region (Dekmejian 1971:39-40, 76-80, 101-8). By contrast, for the last couple of decades, Arab leaders have attempted to educate their publics as to the constraints they face in pursuing Arab nationalist ambitions or the benefits to be derived from abandoning them. Thus, from the time he took power, Asad attempted to lower the Syrian public's expectations from the aim of liberating Palestine to that of recovering the occupied territories. Sadat's Egypt and Jordan's King Hussein campaigned for their peace treaties with Israel, promising that they would bring prosperity to ordinary people. 
One would expect public opinion to play a greater role in the foreign policy process where regimes have electoral accountability mechanisms. In the Arab world, increased susceptibility to public opinion from even limited democratisation put pressure on elites to distance themselves from the West: it was those Arab states which were experimenting with democratisation - Tunisia, Jordan, Yemen and Algeria - that proved most vulnerable to pro-Iraqi public sentiment during the Gulf War. As the cases of Turkey and Israel suggest, if elites can win public support through nationalist rhetoric, the effect of elections may be less to restrain than to encourage elite foreign policy activism. But elections do give the public the ability to punish these elites when things go awry, as several Israeli prime ministers have found out (see chapter 6, pp. 146-7; chapter 7, pp. 186-7).

Even in personalistic and authoritarian regimes the public can sometimes play an indirect role in affecting foreign policy. Especially when the state is weak or state elites are in a power struggle or when they fear the opposition can effectively use foreign policy issues against them, informal mechanisms of accountability may operate. Fear of public reaction can constrain 'reforms': the 'food riots' that have been a region-wide response to structural adjustment deterred regional responsiveness to pressures from international institutions and arguably slowed the region's integration into the world capitalist economy. When the public is aroused and unified by a crisis with Israel or the West, it may even play a role in forcing decisions that elites would not otherwise take. Thus, Sadat faced intense public despair at the 'no war-no peace' situation in the early 1970s, making even a risky war preferable to doing nothing; in Jordan when the public was intensely aroused by the 1967 and Kuwait crises, the same King who at other junctures defied the public, was pushed by public pressures into policies at odds with the interests of his regime (Salloukh 1996). The case of Iran, where the Shah's pursuit of policies in defiance of nationalist and Islamic opinion helped stimulate a revolution which turned those policies upside down, is quite exceptional, but a precedent of which other leaders have not been un-mindful.

Economics, business, and foreign policy making The extent to which the bourgeoisies of the Middle East can or even try to act as a political force or foreign policy pressure group, is debatable. The 
Syrian bourgeoisie's opposition to Nasser's statist policies helped to engineer the break-up of the UAR and at the time Nasser reputedly perceived a comparable threat from its Egyptian counterpart (Dawisha 1976: 106), but this appears an exceptional case. Business is relatively weak, especially in the Arab world: the top twenty Middle East companies are in Israel, Turkey or are Gulf-based, oillinked or banking firms. Rent and indirect taxation such as import duties relieve most states of dependency on the bourgeoisie for tax revenues, which might give the latter the leverage to demand a share of power, and business is often quite dependent on the state (for contracts, licenses, etc.). Business lacks the institutionalised access and clout it enjoys in developed capitalist states: in the authoritarian republics, the military and bureaucracy and in the monarchies, royal families dominate foreign policy making. In more liberal states such as Israel and in Turkey, where a more developed bourgeoisie is well organised in business associations such as the Turkish Association of Industrialists and Businessmen, the bourgeoisie appears better equipped to lobby for its interests as a class; but in both states it takes second place to the national security establishment in foreign policy matters.

Nevertheless, the foreign policy choices that states make are intimately connected to their internal socio-economic structure, specifically, the social composition of the ruling coalition, the resulting relation between the state and business, and the logic of the development strategies these coalitions imply. Thus, in Marxist thinking, the trajectory of Third World states has been intimately shaped by the relative power of the internationalised 'comprador' bourgeoisie - bankers, import-exporters, agents for foreign firms - which is seen as a vehicle of Western influence versus that of the 'national bourgeoisie' - local industrialists - whose interests are compatible with an independent national economy (Hussein 1973). Where an alliance of a radicalised military and a national bourgeoisie is ascendant, the latter's demands for protection from foreign competition will overlap with the former's desire to construct a base of national power. The nationalist foreign policy such an alliance asserts requires easing or diversifying foreign economic dependence - in the Cold War era by relying on the Soviet Union for aid, technology and markets.

By contrast, the oil monarchies incorporate alliances with tribalcommercial bourgeoisies which, living on petroleum rent, Western 
investments and middleman operations with the Western market, have a clear interest in pro-Western foreign policies. In states such as Egypt and Tunisia, the new infitah bourgeoisie is likely to advocate the liberal foreign economic policies needed to establish an attractive investment climate and attract foreign partners; such bourgeoisies, integrated into globalised money markets, enjoy leverage over governments from their ability to damage the local economy through capital flight. Where the top political elite are themselves major business operators and investors - the ruling families in the Gulf states, the Turkish military, the presidential clan in Tunisia - the personal ties and interlocking interests among overlapping political and business elites may be decisive.

A major issue is whether globalisation is increasing the power of internationalised (infitah) bourgeoisies to advance the integration of the Middle East into the world economy and whether this is likely to spread the 'zone of peace' to the region since such economic integration arguably requires the resolution of regional conflicts and an end to nationalist challenges to the West. In fact, even where business has influence, it does not necessarily speak with one voice. While it might be expected that business would lobby for the enforcement of internationally accepted legal standards and for cooperation with the neo-liberal prescriptions of international economic institutions, it is by no means a monolithic champion of unrestrained global integration. On the contrary, it is likely to be divided between merchants and bankers with a stake in international trade and finance and local industrialists who flourish on state protection, subsidies and contracts. Industrialists themselves may divide between exporters and importers over such issues as the exchange rate of local currencies. Rentier capitalists flourishing on privileged connections to the state may lack an interest in universalistic standards of law and regulation.

It is normally assumed that the economic interests of capitalists affect their stances on foreign policy issues but, just as their economic interests are competitive, not uniform, so they are not monolithic on many foreign policy issues. Most business elites are probably more pro-Western than other parts of the population because their interests tie them to Western markets and partners. They may be more dovish on war/peace issues than other parts of the population because peace, in reducing the role of the military, would increase their influence, and would provide a better investment 
climate and opportunity for foreign joint ventures. Leaders pursuing dovish policies usually attempt to co-opt business with promises of the new business opportunities improved external relations would encourage. Sadat pursued this policy, but initially Egyptian business was by no means an enthusiastic advocate of a separate peace with Israel, which threatened to isolate Egypt from the Gulf and Arab markets it needed. On the other hand, the Egyptian-American Business Association subsequently emerged as a powerful block with a stake in joint ventures with American firms and in the flow of American aid to Egypt that rewarded this separate peace. Syrian businessmen are often as nationalistic as other citizens and fear peace with Israel could bring Israeli economic competition, not just investment opportunities. Palestinian businessmen, insecure in the Diaspora and convinced security for their wealth required a state of their own, funded the PLO (Smith 1986). Many Jordanian businessmen boycotted an Israeli trade fair to protest Israel's reversion to hard-line policies after Oslo. In fact, to the degree they are seeking Arab markets, Arab businessmen may be Pan-Arab nationalists and fear Israeli economic competition under peace. The Turkish bourgeoisie, perhaps the most developed in the region outside of Israel, has an internationalist wing in partnership with MNCs which is a strong advocate of entry into the EU and a provincial Islamic wing. The latter, more oriented to the domestic market, provided support for the Islamic Refah party which called for a reorientation to regional Islamic markets. On the whole, Middle East business cannot yet be seen as an engine of 'internationalist coalitions' able to redefine states' foreign policy agendas.

\section{The national security bureaucracies: the pivotal role of the military}

The role of the military in the policy process carries greater weight in most Middle Eastern states than elsewhere. The military literally founded most of the authoritarian republics and remains the central pillar of these regimes; in 1999, presidents were officers or ex-officers in Egypt, Syria, Libya, Tunisia, Algeria, Yemen, and Sudan. In most Middle Eastern states the military was, for a long time, the most developed, modernised and weighty institution in the political system.

The political role of Middle East militaries has, however, changed significantly over time. In earlier periods when traditional landedcommercial elites ruled, the military, recruited to a great extent from 
the rising middle classes, expressed their desire for the reform or overthrow of the old order, and the narrow-based old regimes offered little obstacle to military intervention in politics (Ayubi 1995: 258-60; Halpern 1963: 251-80; Trimberger 1978). However, as the military became politicised, it often fragmented along sectarian, regional or personal lines. Factions vying for political power destabilised Syria in the 1950s and 1960s and Iraq for a decade after the revolution of 1958 . The military might be colonised by particularistic interests, as in Syria where the Alawi sect came, as a result of intra-military political struggles, to dominate the officer corps. Intra-military struggles often damaged the military as a fighting force, discrediting military involvement in politics; thus, the 1967 defeat discredited military politicians in both Egypt and Syria and enabled political leaders, themselves from the military, to appoint professional commanders who rebuilt military discipline. But it often took a power struggle for rulers to establish their authority over the military. In Egypt, for example, Sadat had to defeat challenges from several politicised officers. Saddam Hussein, a civilian, relied on the party and security forces to defeat or deter challenges from the military, often pre-empting them by purges and executions.

As state-building strengthened civilian institutions and authority of office, the vacuum that had originally encouraged military intervention was filled. The military relinquished overt political leadership in many states and became more professionalised, depoliticised and therefore more subordinated to quasi-civilian political control. Policy makers were freed from the factional instability that had hitherto frustrated coherence in foreign policy making. Nevertheless, the role of the military in policy making remains central. Political leaders cannot dispense with military support to acquire office and the propensity of the military to intervene in politics, though declining, requires that rulers attend to its concerns or risk instability. The Minister of Defence, normally an officer, represents the military in the government as much, or more, than he ensures government control of the military. The high salience of national-security concerns and hence the influence of national security elites ensures that the de-militarisation of the polity remains within limits - even in Turkey and Israel. As the case of Turkey shows, even a professionalised military may reserve the prerogative to intervene in politics when the politicians are perceived to put national stability and security at risk. Militaries have usually considered themselves entitled to 
a decisive voice in matters of war and peace, and are self-appointed defenders of the borders and integrity of the state whether from internal or external threats. Professionalised militaries routinely operate as pressure groups on behalf of arms purchases, and for better pay and conditions for soldiers, and their weight is enhanced by a continuing perception of high external or internal threat. Periodic cycles of modernisation needed to keep up with the new generation of weaponry mean the military's voracious appetite for scarce resources can never be sated, locking it into zero-sum conflicts with civilian groups over national budgets. In the 1980s when arms purchases were at their height, Iraq, Syria and Israel - all of which experienced wars - devoted 23 per cent, 18 per cent and 15 per cent respectively of their GNPs to the military and Saudi Arabia and Jordan 17 per cent (Korany, Noble and Brynen 1993: 305). Egypt, Syria, Iran and Turkey had around a half million men under arms and Iraq a million. Moreover, the military has everywhere extended its reach into the economy, becoming, to an extent, a state within a state, founding not only armaments industries but others aiming at self-sufficiency in everything from food to housing (Ayubi 1995: 270-3; Sayigh, 1993; Zartman 1993: 249-54).

Perhaps most dramatic has been the gradual transformation in the ideological outlook of militaries. In the 1950s and 1960s, young Arab officers were radical, modernising and nationalist in orientation; the Egyptian officer corps saw itself as 'defender of the revolution' - until the 1970s. However, as the military became a pillar of ruling establishments, as it accumulated privileges and, especially where it went into business 'on the side', the military elite became a main component of the state bourgeoisie with a stake in the status quo. Everywhere, as a result of this process, officer corps have been de-radicalised, becoming less nationalist, less populist and more supportive of capitalism (Ayubi 1995: 273-6; Picard 1988). Moreover, because the military is typically secular and because mass opposition to regimes has come to be expressed in Islamic terms, the military has become the bastion of secularism against Islamic radicalism. This combination of conservatism and secularism is most obvious in Turkey where, in the name of Ataturk, the military has regularly intervened against the left and more recently against Islamists. It is also apparent in Algeria, Egypt and Syria where the military has repressed Islamist movements. Only in Iran has the military itself been Islamised, although Islamic penetration of the lower ranks of 
the military is probably widespread elsewhere (Ayubi 1995: 264-5). However, the armies that once challenged imperialism or championed Pan-Arabism have for the most part become shields of state autonomy from societal challenges, often enforcing re-integration into the world capitalist market.

Nevertheless, there remain certain variations in the political orientation of Middle East armies and in their effect on the state's foreign policy, in good part owing to differences in their historic roles and bases of recruitment; this can be illustrated through a comparison of the Syrian and Turkish armies.

The military in Syria: persistence of a 'praetorian' army Syria is a case where a radicalised military led a revolution from above and where its special social composition - rural and plebeian - imparted a radical nationalist, populist thrust to the state, the residues of which continue to make a difference for Syria's foreign policy orientation.

The radicalisation of the Syrian army was partly a function of its predominately lower-middle-class and ex-peasant social composition. Recruitment under the French from the Alawi and Druze peasant minorities into the local military forces established a tradition of military service as a route out of poverty for them which continued after independence. The sons of the Sunni upper class, on the other hand, eschewed a military career (Van Dusen 1975: 124) and the small contingent of urban upper-class officers was decimated as a result of the purges following Western conspiracies against the nationalist government in the late 1950s (Seale 1965: 37, 48, 119).

The politicisation of the officer corps was a function of its formation in a time of nationalist ferment. The loss of Palestine, blamed on the corruption and incompetence of the traditional civilian elites, was the direct catalyst of army intervention in politics. In the face of the Israeli threat, the army was rapidly expanded and the military academy provided scholarships to bright underprivileged applicants; as a result, Sunnis from the provincial lower middle class and the peasantry were also increasingly recruited into the army. Indeed, by 1952 , a majority of graduates were rurals. Particularly under the influence of the radical politician, Akram al-Hawrani, youth entered the military academy with political motives: an army career began to be seen as a vehicle of political activism. The sons of impoverished Alawi smallholders or sharecroppers under Sunni landlords 
imbued with agrarian radicalism flocked to radical parties, notably the Ba'th, before entering the army. Subsequent developments, such as Israeli attacks on army positions at the front and the Suez War, reinforced and accelerated the radical politicisation of the officer corps. But political intervention split the army into factions in the 1950s and 1960s, making Syria the symbol of military praetorianism. It was from this crucible that a small group of Ba'thist officers carried out the 1963 coup which brought the Ba'th party to power (Devlin 1976: 204; Perlmutter 1969: 835).

From the moment Ba'thi officers brought the party to power, they were the senior partner in the new military-party state. In the first years after the power seizure, the Ba'thi 'military committee', a secret organisation of Ba'thist officers dominated by Alawis and Druze, acted as a unified body to extend its control over the army through massive purges and wholesale recruitment of politically loyal new elements, frequently Ba'thist teacher/reserve officers. This Ba'thisation of the army turned it into a rural and, increasingly, a minority stronghold. These officers also worked to achieve dominant roles in party and government institutions. The army's Ba'thisation infected it with all the Ba'th's internal conflicts while the militarisation of the Ba'th meant that such conflicts were decided as much by the command of tanks as by votes in party assemblies. The resultant recruitment, dismissal and promotion of officers on the basis of political loyalty displaced professional standards and as sectarian solidarity became a shorthand for loyalty, intra-Ba'th power struggles led to the decimation of non-Alawi groups in the army. Initially, Alawi officers appeared the most militantly radical force within the $\mathrm{Ba}$ th, the most intense carriers of peasant grievances against the urban establishment. Their strong solidarity, as opposed to the more regionally and class-divided Sunni officers, accounts for their success in establishing political ascendancy (Drysdale 1979; Rabinovich 1972; Van Dam 1981).

After a 1966 radical coup within the Ba'th regime, the victors tried to transform the military into an 'ideological army' committed to Ba'thism whose coercive power would give the regime the autonomy of the dominant classes necessary to launch the Ba'th revolution from above: indeed, in the following years the army repressed no less than seven major anti-regime urban disturbances by some combination of merchants aggrieved at state socialism and Islamists alienated by minority dominance. However, once the radical 
Ba'thists' politicisation of the army was discredited by its miserable performance in the 1967 war, they rapidly lost support among the officer corps. The moderate Ba'thist Defence Minister, General Hafiz al-Asad, asserted control over appointments and transfers in the name of rebuilding the army's professional standards and this allowed him to eliminate his rivals and seize power in 1970: when party authority and Asad's military command clashed, the latter triumphed easily (Van Dam 1981: 83-97).

Under Asad, the military, apparently triumphant, was gradually turned from a vehicle of regime change into one of several pillars of state subordinate to the presidency. As Drysdale (1979) points out, Asad pursued a dual policy in seeking to reconcile Ba'thist political control and military professionalism. On the one hand, praetorian guards units primarily charged with regime defence and certain coup-making armoured units were recruited on the basis of political loyalty and (Alawi) sectarian and kin affiliation. On the other hand, equally preoccupied with the conflict with Israel, Asad put a new stress on professional competence and discipline in the wider army and purged non-political officers were reinstated. Steadily expanding in size and benefiting from a 'cornucopia of sophisticated modern weapons', the reformed Syrian army acquitted itself respectably in subsequent conflicts with Israel (Drysdale 1979: 372; Picard 1988).

This strategy, together with the social and political congruence between the top political and military leadership, elaborate police surveillance of the army, and its increasingly privileged position in society, helped Asad to end the long era of coups, an achievement crucial to his stabilisation of the Syrian state. Moreover, the steady expansion in the size and firepower of the military made violent opposition to the regime very costly, if not futile: the Alawi military showed the extremes to which it would go to protect the regime in its 1982 bombardment of an Islamic uprising in Hama. By the 1970s, the once radical officer corps had become an integral part of a new political establishment with a stake in the status quo. It was a powerful interest group advocating increased defence spending and especially influential on security issues and matters of war and peace with Israel. Senior politicised officers still manoeuvred to insert allies and clients into top party and government posts and ambitious politicians sought their backing. Ex-officers headed ministries and officers ran military-owned companies, were involved in 
smuggling rings or acted as brokers allocating state contracts and goods to clients (Picard 1988: 139-44). Seemingly immune from accountability, they became major obstacles to attempted reforms of the corruption and power abuses in the regime. Moreover, in alliance with the revived Damascene Sunni bourgeoisie, they came to constitute a 'military-mercantile complex' bridging the 'new' state and 'old' private bourgeoisies. Nevertheless, continued recruitment of the military from Alawi villages and sectarian barriers to intermarriage between Alawis and the Sunni bourgeoisie, were major obstacles to amalgamation of these elites into a new unified upper class. Because the Sunni bourgeoisie was still better situated to benefit from manipulation of the market and the Alawis from exploitation of the public sector, the Alawi military remained a brake on the economic liberalisation which was integrating other Middle Eastern countries into Western-dominated markets. The military also retained a residual commitment to Arab nationalism and militancy toward Israel that was reflected in the country's foreign policy.

The Turkish military: above and against society? In Turkey the military historically has had a strong sense of institutional identity. Its view of itself as the guardian of the interest of the state against particular societal interests was manifested in three coups carried out against elected governments. But the social composition of the officer corps inevitably shaped its conception of this interest, which evolved over a century from a radical modernising to a conservative one.

The military became a key actor in defensive modernisation from the beginning of Ottoman reform when the defence of the empire became inseparable from its rapid modernisation against the resistance of 'traditional forces'. The military was a key support for modernising ministers and, when reform failed to ward off external threats, it became a vehicle for a more radical revolution from above under Ataturk which preserved while reshaping the state (Ahmad 1993: 3-4).

This does not mean that the army was isolated from and unreflective of society. Liberal versus radical cleavages among officers under the Young Turks and under Ataturk tended to reflect the social strata from which such factions were recruited. However, Ataturk used his prestige to insulate the military from politics, turning it into a reliable and professionalised instrument of his 
regime. Then, in the post-Ataturk period, the military assumed the role of defender of the Kemalist heritage, although its interpretation of Kemalism altered as its social composition changed (Ahmad 1993: 6-9).

The 1960 coup, launched in the name of defending the Kemalist revolution, was the last gasp of military radicalism. It was engineered by junior officers of provincial lower-middle-class background resentful of the Democrat Party government - and the co-opted top brass - which impugned the army's prestige and allowed inflation to so erode military salaries that officers experienced downward mobility even as the new business class was enriched (Ahmad 1993: 9-10,121-5). The coup opened the door to a further democratisation of the political system and an opening to the left, which included allowing workers the right to strike and the formation of a socialist party.

This experience taught the military high command and the state establishment that the army had to be given a vested interest in the system if future revolts against senior officers were to be prevented. After the coup, centrist senior officers under General Gursel got the upper hand, radical officers were purged and the high command began the systematic policing of the political attitudes of the officer corps. The army's role as guardian of the state was institutionalised in the National Security Council in which the high command acquired the right to regular consultations with the cabinet. At the same time, the officer corps was turned into a privileged elite, enjoying high salaries, pensions and perks. Retired officers were recruited into state-run businesses and a military industrial complex emerged. The Army Mutual Assistance Association began investing officers' pension funds in private business, becoming the full or joint owner of auto, insurance and petro-chemical companies, including a partnership with Renault of France. The officer corps thus became an extension of the bourgeoisie with a stake in stability and order. It became increasingly sympathetic to the conservative parties which advocated market capitalism and alienated from Ataturk's old Republican Peoples Party (RPP) as the latter reinvented itself as a social democratic party appealing to the middle and lower classes and took a stand for a more independent, less pro-North Atlantic Treaty Organisation (NATO) foreign policy. The 1971 coup, while made in the name of order, targeted the left while tacitly encouraging the forces of the right (Ahmad 1993: 130-2). 
This tendency reached its full dimensions in the next 1981 coup under General Kenan Evren. The coup, according to Ahmad (1993: 174-80), in part reflected the growing responsiveness of the top military to US government perceptions and interests at a time when the Iranian revolution and the Soviet invasion of Afghanistan heightened the American need for a reliable ally in the region. The centreright Demirel government was resisting US requests to situate its (anti-Iranian) rapid deployment force in Turkey, would not make the concessions to Greece needed to protect the cohesion of NATO's south-eastern flank, and was dependent on the anti-American Islamic Salvation Party. The military, bypassing the government, made concessions to Greece and forced the signing of a defence agreement with Washington which restored military aid suspended over Cyprus. At the same time, Demirel began to implement an IMF austerity plan which removed subsidies, reduced protection for industry and started a shift from import substitute industrialisation to the export strategy required to pay Turkey's debts; but massive worker strikes resisted this and the RPP and Islamic Salvation Party came together to oppose closer links to the West. This precipitated the coup that put an end to the 'disorder' that made Turkey seem a dubious ally for Washington. The military regime embraced the economic liberalisation and structural adjustment measures of Turgut Ozal's new government and provided the repression of labour needed to enforce it. Foreign policy was reoriented to a close US alliance. A new constitution invested the military dominated National Security Council with responsibility for protecting the integrity of the country and gave it the sole right to interpret its own mandate: in short, elected politicians became accountable to the military, not the reverse.

The military was not, however, a complete monolith. In the mid1980s, as civilian rule was restored and Ozal emerged as the dominant political leader, a new test of the political power of the military developed. An ambitious general and leader of the 1980 coup, Chief of Staff Necdet Urug was positioning himself to succeed to the presidency after General Evren; contemptuous of civilians and little Westernised, he had antagonised Washington by objecting to some of its co-operation proposals. With US support - and that of President Evren - Ozal passed over Urug's candidate to succeed him as Chief of Staff in favour of a Westernised general, and then - in a 'civilian coup' - had himself elected President instead of the 
expected military candidate. Similarly, when in 1992 the Chief of Staff resigned in protest of Ozal's close alignment with the US against Iraq, the military was too divided to act. While it is usually the military that is united and the politicians divided, when the opposite is the case, the military can be restrained (Ahmad 1993: 213-18; Mufti 1998).

By the mid-1990s, however, the more usual situation had been restored: weak civilian governments faced a more politicised military seemingly united against perceived threats from the Kurdish insurgency and the rise of political Islam. The military not only carried out a virtual coup against the Islamist prime minister, Necmettin Erbakan, but by-passed the politicians in striking a close military alliance with Israel supposedly needed to win US support for the counter-insurgency against the Kurds. Links with Israel were also seen as crucial to the military's massive modernisation program. The military appeared increasingly determined to impose its own conception of Turkey's national security needs on the political system.

\section{Decision-making structures: variations in the concentration of power}

The state structure - the features and coherence of institutions and the way they distribute power and channels of influence in the policy process - determines actual foreign policy choices.

In the Arab republics, often thought to approximate the leaderdominant model, the chief executive does enjoy wide discretion and autonomy in foreign policy making. Presidential dominance is typically enshrined in constitutional distributions of powers: the president has the main, if not the exclusive, right to conduct foreign policy and is commander-in-chief of the armed forces. He is little constrained by standard operating procedures or formal checks and balances. Yet, the president's actual ability to exercise his formal powers of office cannot be taken for granted. Even in Egypt, which has the most institutionalised presidency, presidential dominance within the top political elite has been the product of power struggles in which the leader had to acquire enhanced personal stature or build sufficient coalitions in order to prevail.

Nasser initially made policy in consultation with his Free Officer colleagues and it was only the growth of his personal charismatic stature combined with the 1956 establishment of a constitution 
endowing the presidency with enormous powers, that elevated him above the rest of his colleagues; even then he continued to meet opposition from other Free Officers and had to rule by exploiting divisions among them (Cremeans 1963: 32-3; Dawisha: 1976: 104-5, 115, 117). Sadat, on assuming the office, immediately asserted Nasser's presidential prerogative. A major issue in the power struggle with left-wing Free Officers in the ruling party after Nasser's death was Sadat's insistence on his unilateral presidential right to make foreign policy decisions such as his offer to open the Suez Canal in return for a partial Israeli withdrawal from its banks and his decision to join the Federation of Arab Republics with Libya and Syria. In the showdown over presidential power, Sadat benefited from the respect of professional officers for the chain of command which the presidency headed, but he had also to build a coalition of more conservative officers, bureaucrats and elements of the Westernised bourgeoisie and he only prevailed because his rivals lacked effective links to their potential constituents among the Nasserite masses. Although Sadat's purge of these rivals gave him a freer hand, before the October 1973 war he still lacked the legitimacy to take the biggest decisions alone; as such, the planning and decision to launch this war was made in close consultation with the military and political elite (Korany and Akbik 1986: 96-9). Even after the war consolidated his stature, Sadat was only able to pursue his intensely personal course toward a separate peace with Israel by a wily step-by-step policy. Had he revealed at the outset that he sought such an end - if indeed he did - much of the Egyptian political elite might well have combined against him; however his first steps along this path - the decisions to seek a diplomatic settlement and a US opening to balance the Soviet alliance - were acceptable to all but hard-line Nasserites. Further steps along the road - expulsion of the Soviet advisors, the decision to launch a merely limited war in the Sinai - had the support of a majority of the elite. The final steps, however - the first disengagement, the second disengagement, the final break with the Soviets, Camp David - were presented by Sadat to the elite as fait accompli, each of which further enmeshed Egypt in a web of commitments while narrowing alternative options (Hinnebusch 1985: 65-9).

Where the president's authority is consolidated, he does normally dominate decision-making. However, in some cases a more collegial or factionalised 'bureaucratic politics' (Allison and Halperin 1972) 
may give other elites, speaking for rival branches of the bureaucracy - army, ruling party, foreign ministry, national security council, intelligence services, etc. - opportunities to influence decisionmaking. Normally, the rival branches of the state seek to advance their own particular role, budgets and solutions, with the chief executive choosing between them. Episodes of conflict between ideological parties and the army were salient in late Nasserite Egypt (the so-called centres of power), in pre-1970 Ba'thist Syria, and in postindependence Algeria. Even where bureaucratic politics is more muted, presidents may wish to consult within the elite in order to generate a maximum consensus behind controversial or risky policies, and a National Security Council may regularise such consultation. The president's national security advisors, who may be part of his shilla - his network of long-time close personal supporters - may exploit their personal relations with him in the battle over policy. While the council of ministers (cabinet) normally discusses a decision after the leader has taken it and is basically a policy implementing body, bureaucratic politics plays a role in shaping the 'normal' day-to-day administration of foreign relations in which the leader's commands may be variously interpreted or distorted by his subordinates. That being said, the scope for bureaucratic politics in the authoritarian republics is normally strictly limited: other elites, typically being the 'president's men', are less likely than in more pluralistic states to identify with the interests of their organisations or to enjoy the support to make them power bases from which to stand up to the president; this, in turn, reflects the lesser institutionalisation of the state in the Middle East (Ayubi 1994: 35; Korany and Akbik 1986: 52-6).

This is even more true of parliaments and the committees of ruling parties, which, subservient to the president, are seldom able to do more than approve executive initiatives. For example, although the Egyptian parliament acquired more power under Sadat's limited political liberalisation, he brushed aside numerous attempts by a near parliamentary consensus, remarkable in a body dominated by the government party, to restrain his march toward a separate peace. These included resolutions to give the Arab Defence Pact priority over the peace treaty with Israel, to make normalisation of relations contingent on a comprehensive settlement, and to link it to the West Bank autonomy provided for in the Camp David accords. Eventually, a fed-up Sadat dissolved this parliament and 
made sure elections to its successor eliminated all leading critics (Hinnebusch 1985: 175).

In some of the Arab monarchies and in the more pluralist regimes, foreign policy making is likely to be more collegial than in the authoritarian republics. In the monarchies, the extended ruling families often constitute an informal consultative group to which the monarch is expected to listen and senior royal princes simultaneously head the various national security bureaucracies. In more democratic states, such as Israel and Turkey, power is more diffused among senior cabinet ministers and military officers, the foreign policy professionals have more influence, and parliaments have more power to hold the executive accountable. In Israel, where the cabinet, in which each minister has one vote, must approve strategic decisions, prime ministers, notably Ben Gurion and Begin, were on several occasions restrained by fellow ministers (Brecher 1972: $211,228,280)$. In semi-pluralist Iran, power is diffused between the spiritual leader, the president, and parliament. Aspects of bureaucratic politics have more scope to operate in pluralist regimes, especially when the top elite is factionalised, and although the chief executive normally has the last word, he or she may have to arbitrate between opposing factions or make concessions to other elites to maintain their support.

Variations in the concentration of power, in the extent of bureaucratic politics, and in the range and character of actors included in the policy process inevitably shape the character of policy outcomes. The typically limited access to the policy process in most Middle East states may narrow the alternatives considered and bias the policies adopted. Foreign ministries in principle provide much of the information and diplomatic skills needed for the conduct of foreign policy but in the Middle East they are, by world standards, weak in professionalism, resources and influence over foreign policy. This means a lack of institutional support (policy analysis and planning) for decision-makers and limited institutional memory to ensure policy continuity. Especially in the authoritarian republics, the foreign minister is likely to be a client of the leader without an independent power base, who can be dismissed with ease, and thus cannot present an independent institutional view. Even in Egypt, the Arab state with the most professional diplomatic corps, the extent to which the president is guided by the foreign minister is, according to Boutrus Boutrus Ghali (1963: 320), who served under Nasser, 
a matter of his personal choice; the ministry as an institution chiefly deals with day-to-day transactions (Ayubi 1994: 8-9, 14). If the diplomats are undervalued, the role of the security and intelligence services is everywhere central to foreign policy making because intelligence bosses are sometimes major political actors and because they are pivotal in the monitoring of both external and internal threats. The exceptions to this picture are only partial. In Turkey the foreign ministry enjoys high prestige and in Israel it is highly professional; yet in both states the military, ex-military politicians, and the intelligence services nevertheless frequently overshadow the diplomats. The limited influence of professional foreign policy establishments, together with the dominance of the policy process by military and intelligence bureaucrats, may give special weight to the advocates of the use of force over negotiation in achieving ends and to 'national security' considerations over other issues, such as economic interests or identity, in the policy process.

The over-concentration and personalisation of power so typical of Middle Eastern states is widely thought to threaten the rationality of decision-making. It may mean a lack of checks on the ability of leaders to translate their idiosyncratic choices into policy. It may obstruct the channelling of sufficient information and policy alternatives to the top decision-makers, making them more prone to miscalculation. Yet, the ideal of a rational actor implies a unified leadership and, where the elite is fragmented by competing factions not effectively reconciled by the top decision-maker, foreign policy issues may become weapons in the domestic political struggle. The outcome may therefore represent less a rational plan to achieve some geo-politically-defined national interest than a reflection of the intra-elite power balance at a given moment. Rationality would seem to be enhanced by a process which combines enough pluralism in the policy process to secure sufficient input into it with a reasonably unified leadership enjoying the legitimacy to make decisions free of constant worries about the domestic power struggle; but this balance appears to be the exception rather than the rule.

There do not, however, seem to be hard and fast rules. The personalisation of power in Iraq under Saddam led to disastrous miscalculations. In Syria, by contrast, the fragmentation of the preAsad Ba'th regime encouraged the factionalist outbidding which led to the disastrous 1967 war while, after Asad's personalisation of power, foreign policy was widely seen to approximate the rational 
actor model. Sadat's personalisation of foreign policy allowed him to pursue a high-risk policy which, overriding the caution of his bureaucrats and advisors, permitted key breakthroughs in reaching peace with Israel. But as a result, mistakes, such as the total break with the Soviet Union and the excessive reliance on the US, were not corrected. Three successive foreign ministers resigned in protest over Sadat's tactics in the negotiations with Israel in which he made seemingly impulsive concessions on matters he considered trivial but which they regarded as crucial. In the Camp David negotiations, Sadat's lack of accountability to other elites or the public meant he could not claim to be constrained by them from making concessions. By contrast, Begin's bargaining hand was strengthened by his claim to be more constrained by his slim parliamentary majority and his hard-line party in Israel's more accountable political system (Telhami 1990: 157-95). Nevertheless, the personality of the leader and whether it is appropriate to the 'needs' of the period may be as important a variable in determining the rationality of decisions as is the character of the policy process.

\section{The idiosyncratic variable: how much difference does the leader make?}

While an uncritical concentration by foreign policy analysts on the leader has been rightly criticised (Korany \& Dessouki 1991: 8-9), where domestic political systems are in transition, as in the Middle East, institutions and standard operating procedures which might constrain the leader are not well established and, indeed, may be the recent creations of the leader himself. Where society lacks strong interest groups or classes, where the tradition of patrimonial rule prescribes loyalty to the person of the ruler and where legitimacy depends on his role as a hero, especially in foreign policy, the leader is more likely to shape public opinion than to be constrained by it (Ayubi 1994: 6-7). The relative absence of institutionalised checks on leaders in the Middle East does not mean there are no informal domestic constraints or pressures on them; the leader inherits the foreign policy role conception of his country which affects his perceptions and preferences and the preservation of regime legitimacy may depend on foreign policy performance in the service of this role (Dawisha, 1990). But rather than being sharply constrained by such roles, leaders, to a considerable extent, construct or re-construct them or implement them in idiosyncratically distinct ways. 
To the extent that foreign policy making is exceptionally personalised in the Middle East, a state's foreign policy performance is more dependent on the leader's personal style, capabilities, values, goals, strategies, perceptions - and misperceptions - than in more institutionalised states. Choices, particularly in a crisis or a critical bargaining situation wherein policy making tends to be especially centralised, are inevitably to some extent idiosyncratic. The relative weight of and role of the idiosyncratic variable can be assessed by comparing different leaders in the same state facing similar situations (Nasser v. Sadat) and different leaders in similar states in the same time frame (Asad v. Saddam).

From Nasser to Sadat To what extent did the change in Egypt's leadership from Nasser to Sadat explain the radical change in Egypt's foreign policy after 1970 - specifically the turn from the USSR to the US and from Pan-Arabism to a separate peace with Israel? Nasser had, it is often argued, started the changes, in his acceptance of the Rogers Plan for a peaceful settlement with Israel under American auspices, which Sadat would take to their logical conclusions. Nevertheless, this decision did not necessarily lead to a separate peace and, indeed, such an outcome would arguably have been incongruent with Nasser's personality.

Nasser was, from his youth, a rebel against a world where unjust force was perceived to govern (Ayubi 1994: 92-3). According to Wynn, the humiliation Nasser experienced from being looked down on for his baladi (plebeian) background sparked a psychological drive to make himself and his people proud, not ashamed, to be Egyptians (Dawisha 1976: 108) As a saidi, a product of upper Egypt's stress on honour and manhood, Nasser was, Dawisha argues, 'almost obsessed' with personal dignity and extremely sensitive to slights. He believed Egypt and the Arabs needed a hero who would battle against superior malevolent powers and he sought this role. It should not be imagined that Nasser's policy simply grew out of irrational or emotional flaws. At a time when most of his Free Officer colleagues were Egypt-firsters, Nasser was the Free Officer with a strategic regional vision, convinced that only together could the Arab states ward off the imperialist and Israeli threats (Seale 1965: 193, 225). His experience in power convinced him, after a period in which he sought accommodation with the West, that the West's interests in the reinforcement of Israel and control of Middle 
East oil were fundamentally at odds with those of the Arabs (Dawisha 1976: 125). But his personality traits lent a particular intensity and tenacity to his anti-imperialist orientation. This orientation was, moreover, powerfully reinforced when Nasser's defiance of the West sparked enormous enthusiasm from the Pan-Arab public; Nasser's charisma grew out of the correspondence between his own experience and that of the man in the street, between his personal values and the dominant mass value system of the time (Dawisha 1976: 129). Once he became a charismatic hero, his personal dignity and Egypt's became, to him, inseparable. Nasser's deepest instinct when challenged was to go on the offensive, to seize the psychological initiative needed to recapture the imagination and enthusiasm of his followers (Kerr 1971: 27, 29). He would not give in to superior power under threat and sought, instead, to mobilise new resources to reconfigure the power balance. He was ready to take risks rather than accept humiliation: the Suez Canal nationalisation, the Yemen intervention, the events leading up to the 1967 war and the War of Attrition - were all partly calculated risks, partly emotional reactions to challenges (Dawisha 1976: 92-3, 95-107).

The stunning defeat of 1967 was Nasser's greatest reversal; but his immediate response was a defiant call for the Arabs not to relinquish the fight against imperialism (Dawisha 1976: 50). Nasser could not abandon his role as Arab hero or give up dignity by submitting to American or Israeli power. He was prepared for a just political settlement but was deeply sceptical of American intentions; US arms deliveries were maintaining Israeli superiority while Israel rejected any return to the 1967 lines. Believing that, in a world where force was respected, one could not negotiate from a position of weakness, he launched a major overhaul and expansion of the armed forces and, in the War of Attrition, contested Israel's hold on the Sinai peninsula (Dawisha 1976: 56-7); only when he had thereby partly righted the power imbalance did he accept the Rogers Plan and a ceasefire.

Had Nasser lived, he would have faced similar constraints to those faced by Sadat and, as an experienced strategist, was pragmatic enough to have similarly mixed diplomacy and concession with military force in seeking to roll back the Israeli occupation (Kerr 1971: 156). But his intense anti-imperialism and the psychological difficulty of reversing the principles on which his heroic PanArab role rested, limited his flexibility in pursuing partial diplomatic 
solutions while his history of conflict with Israel and the US made them little interested in accommodating him. To the end, he rejected a separate solution (Dekmejian 1971: 99-101; Vatikiotis 1978: 266-309). Had Nasser not died young, Egyptian policy in the post1973 peace process would arguably have more closely resembled that of Syria under Asad and have been pursued in co-ordination with Syria. Whether this would have resulted in a comprehensive settlement is debatable but it might have preserved the Arab leverage that was dissipated by Israel's ability to divide its opponents.

However much Egypt's deteriorating economic and military situation may have made Anwar al-Sadat a man appropriate to his time, his policies were by no means inevitable for, far from expressing an intra-elite consensus, he repeatedly made decisions in defiance of elite opinion and these were quite distinct from those of his predecessor: if, when facing superior power, Nasser's instinct was to 'balance' against it, Sadat's was to 'bandwagon' with it. Arguably also, Sadat's personality traits and personal style made a decisive difference in Egypt's negotiating stances and the sub-optimal separate peace reached with Israel. As Ajami suggests, his desire to be accepted by the West led him into wishful thinking. According to his Foreign Minister, Ismail Fahmy, he was 'consumed by his desire to become an international hero' in Western eyes and Kissinger is said to have admitted that Sadat squandered the leverage from the 1973 war and the oil embargo out of the weakness to be acclaimed as a 'hero of peace'. He personalised relations between states, naively convinced that his embrace of American leaders, including his 'friend Henry' (Kissinger), would be enough to change America's pro-Israeli policy. His eagerness to jettison Soviet support and rely totally on American diplomacy was an eccentrically personal choice that appalled his professional foreign policy advisors. To Sadat, the Russians were 'crude and tasteless people' while Egypt's alienation from the US was unnatural, not the result of a conflict of national interests but a matter of misunderstanding (which he would put straight) or a product of Egypt's Soviet alliance (which he would abandon) or of Israel's influence (which could be overcome by embracing a US alliance). This craving for acceptance by the West was, paradoxically, paralleled by over-confidence. A big-picture thinker, uninterested in details, Sadat completely lacked Nasser's voracious appetite for information and did not like reading the reports of his foreign policy advisors. Seeing himself as a 'master of 
decision' whose 'electric shock diplomacy' would upset the ArabIsraeli status quo, he was unwilling to heed the advice of the foreign policy professionals and enjoyed surprising them by his personal initiatives. In negotiations over Sinai I and Sinai II, the disengagement agreements with Israel after the 1973 war, he excluded his top advisers from key sessions with United States Secretary of State Henry Kissinger and overrode their objections to many details of these agreements, disregarding the warning of his senior general that these agreements would forfeit the military option. He made his momentous decision to go to Jerusalem without even bothering to create an elite consensus behind him and allowed his top generals little say at Camp David (Ajami 1981: 102, 109-16; Dessouki 1991: 168-71; Fahmy 1983: 14, 72-4, 136-7, 173-5, 283-90; Heikal, 1978a: 75-9, 113-16; Heikal 1983: 71; Karawan 1994: 250, 257; Sadat 1978: 93-5, 107-19).

Telhami's analysis (1990) of the bargaining at Camp David gives sharper focus to the impact of the idiosyncratic factor. While Telhami accepts that the power asymmetry with Israel was decisive in forcing Egypt to seek a negotiated solution, he argues that the role of leadership in the bargaining process decided the exact terms of the settlement in Israel's favour. At Camp David and thereafter, Israel got all that it wanted - a peace treaty which took Egypt out of the Arab-Israeli conflict and left it free to incorporate the West Bank/Gaza area - while Egypt failed to get recognition of the principle of Palestinian rights, failed to link normalisation of relations with Israel to progress on the Palestinian front, and failed even to get a freeze on Israeli settlements during the negotiations over Palestine. Had Egypt been more successful in its diplomacy, it might not have had to sacrifice its Arab leadership to attain peace.

Bargaining theory advises keeping the opponent uncertain of your bottom-line position. But Sadat had a history of making concessions in advance. At his first meeting with Kissinger, he reputedly declared that he was finished with the Soviets and that Egypt had fought its last war with Israel (Heikal 1983: 75); in 1978 he told Israeli Defence Minister Ezar Weizmann that he would make peace whether or not Israel conceded a Palestinian state (Fahmy 1983: 289). At Camp David, he told President Carter he would be flexible on Egypt's official demands for a comprehensive peace; predictably, once the Israelis learned this, they became more unyielding. Theory also advises that the top man should not negotiate alone or settle the 
details and should allow subordinates who have limited authority to prepare the way, but Sadat personally negotiated everything. Sadat's wishful thinking, his unwillingness to engage in a sustained power struggle with Begin and his overconfidence led him to rely on Carter to secure him an acceptable outcome.

By contrast, Begin was a strategic thinker who never lost sight of his strategic dream of a Greater Israel incorporating the West Bank. Yet, he kept his eye on the details and never let his bottom line be known. He bargained stubbornly, starting from an extreme position, i.e. making such a fuss over retaining Israel's Sinai settlements that he diverted attention from other issues and was able to give the impression that he had made a big concession when he gave way on the issue. So stubborn was Begin that when Carter faced deadlock, he went to Sadat for concessions - and got them. According to Telhami, Sadat failed to understand that Begin also needed and wanted a deal and hence gave in too readily to what would be a separate peace. After Camp David, Sadat's yearning to be the hero of peace made him so impatient with diplomatic bargaining over the Egyptian-Israeli peace treaty that he undermined the efforts of Egyptian negotiators to establish a firm linkage between the treaty and the actualisation of the accompanying autonomy agreement for the Palestinians: Sadat destroyed their hand when he let if be known he would proceed with the former without the latter (Heikal 1983: 74-5; Telhami 1990: 157-95).

It is not that Sadat's personality wholly explains the course Egypt took; much of the foreign policy establishment - even Nasser for that matter - constrained by Egypt's limited resources, would have adopted similar strategies of trying to manipulate the superpowers to obtain a negotiated settlement with Israel; where Sadat made the difference was the poor hand he played in this game and the suboptimal outcome he achieved.

Asad v. Saddam Syria and Iraq are ruled by branches of the same party and have similar leader-army-party authoritarian regimes that profess the same ideology of Arab nationalism. Both leaders rose to power from the lower strata of society and the socialisation of both took place in the heady days of Nasserism. Both were men of pride and self-confidence, intolerant of opposition. Both enjoyed nearabsolute power over foreign policy making. But there the similarity ends. Their foreign policy decisions could hardly have led to more 
contrasting outcomes. Asad turned Syria from a victim of stronger neighbours into a formidable player that was generally thought to punch above its weight in foreign affairs. Iraq, on the other hand, enjoyed the most balanced combination of power resources in the Arab world, but Saddam Hussein, in the course of two devastating wars, dissipated these resources and turned Iraq into a victimised pariah state. Do the personalities and attitudes of the leaders explain a significant part of this different outcome?

According to Seale (1988: 492-5), Asad was 'a man of 1967': his harrowing experience when, as Defence Minister, he saw his unprepared forces mauled in a war brought on by the recklessness of ideological-minded colleagues, decisively shaped his outlook. He learned 'realism' which he compared with the 'ideology' of the pre$1970 \mathrm{Ba}$ th radicals who, fatally neglecting the balance of power, gave Israel an excuse to attack Syria. With a strong sense of Syria's limited resources, aware that he could not afford to make a mistake, that, in Seale's words, at every stage he risked being knocked out of the game, Asad developed qualities necessary for battle in a tough environment. According to Ma'oz (1988: 32, 34, 41-2), Asad demonstrated a 'winning' combination of traits: consistency, patience, caution, coolness and shrewdness. Aided by his huge capacity for work and excellent memory, he never succumbed to wishful thinking or moved without a thorough analysis of the balance of forces. He was ruthless but used violence with economy, while reserving the carefully calibrated use of military force for the right time and place.

Saddam Hussein was almost the opposite kind of personality: a man of 'pent-up violence' with little sense of limits. Having begun his career as a street fighter, his courage and fearlessness gave him a reputation as a shaqawah - a tough man to be feared. He rose to power through a combination of conspiracy, organisation and violence, including the Stalinist-like terror and purge of all who stood in his way. Saddam admitted to an admiration for Stalin and his favourite movie was said to be The Godfather. It may not be an exaggeration to say that he epitomised a political culture where personal strength and ruthlessness enjoyed high respect, arguably reflective of the Iraqi yearning for order amidst the chronic instability that followed the 1958 revolution. In foreign affairs, Saddam proved to be a high-risk taker with grandiose ambitions sought through resort to violence. Arguably, Saddam externalised in the international realm the violent political methods that had served 
him so well at home. But he overestimated the international permissiveness for such methods and repeatedly miscalculated the will and capacity of his opponents - Ayatollah Khomeini, President Bush to oppose his plans. For example, expecting Iran to quickly submit, he had no fall-back strategy once his initial attack failed to unseat Khomeini (Devlin 1992: 1052; Khalil 1989: 118-20; Marr 1985: 218-20; Miller and Mylroie 1990: 24-41).

It is hard to escape the conclusion that leadership does indeed make a big difference. Outcomes therefore depend on whether the leaders' qualities match the requirements of the external situations in which they operate. Sadat was a wishful thinker who underplayed his hand and was victimised by the stronger personalities of his rivals, Asad and Begin were rational actors best able to combine limited goals with flexible means, while Saddam's risk taking led to gross miscalculation that squandered Iraq's power. The differential results of their policies validate the realist maxim that success in international politics depends on the prudent and effective use of power. But the differences in their uses of power appear so largely idiosyncratic that pluralism's concern with leadership psychology and perceptions seems vindicated. 